\title{
Power to the People or Power in the People, Reflections on the Nigerian Democratic System: Implication for Policy Development
}

\author{
Ernest Osas Ugiagbe, PhD \\ Department of Socral Work, University of Benin \\ Benin City, Email: ernestugiagbe@yahoo.com \\ Oseye, Sunday, Omigie, Msc \\ Department of Social Work, University of Benin, Benin City \\ Email: sunnyuniben@yahoo.com
}

Doi:10.5901/ajis.2014.v3n4p247

Abstract

Democracy is often applauded as government of the people wherein power belong to the electorates and the people who elect their representatives to represent and protect their interests. But the ideals of democracy as practiced in advanced Western World do not obtain here in Nigeria. This paper examines the democratic ideals in Nigeria in the present political dispensation. The paper attempts elucidation of the loci of power and authority in Nigeria-is it the electorates/people or the elected and political office holders? The attitudes and behavioral dispositions of office holders towards the people who elected them were $x$ rayed. The submission of this paper is that power belongs to political office holders and their cohorts and not the Nigerian people. The political office holders use their wealth and connections to oppress and dominate the electorates who ideally they are suppose to serve and defend. The policy implication of the issue being examined was discussed and recommendations were made on the feasible way forward.

Keywords: Authority, Power, Electorates, Democracy, political office holders.

\section{Introduction}

There has indeed been a trend towards greater democratization and freedom in the world in the past decades. Freedom House which compiles a yearly international survey of the status of political rights and civil liberties, the number of countries around the world classified as 'free from tyranny' has grown significantly in recent years' (www.freedom house.org). However, this positive trend is tempered by the large numbers of people still living under conditions of tyranny though under democratic government (Sharp, 1993).

Many countries today are in a state of rapid economic, political and socio-cultural change. Although the number of 'free countries has increased in recent years, there is a great risk that many nations, in the face of rapid fundamental changes, will move in the opposite direction and experience new forms of dictatorship. Military cliques, ambitious individuals, elected officials and doctrinal political parties will repeatedly seek to impose their will. Basic human and political rights will continue to be denied to vast numbers of peoples (O'Hegarty, 1952). Nigeria is unarguably one of the nations of the world which are going through turbulence as a result of the usurpation of power and authority of the state by very few cliques who do everything to repress the will and aspirations of the generality of the people.

In Nigeria today, it is difficult to unequivocally say that power resides or belongs to the people - the electorate or masses as they are popularly known in Nigeria. What is actually the power-authority relation between the people and government of Nigeria? Where exactly are the loci of power and authority in Nigeria. Is it with the passive and powerless poor masses or with the demi-god political aristocrats, all powerful elected officials or the political jobbers within the polity? These are some of the questions this paper will attempt to answer. This paper will attempt to unravel the loci of power-authority structure in the Nigerian polity in the context of who call the shorts - the few elected political class and their cohorts, praise singers, sycophants and bootlickers or the teeming Nigerian population who 'elect' them periodically as alter ego of the people.' 


\section{Conceptual Clarification}

The notion of power-authority relations is modelled from a historically specific condition: the emergence of the modern European western nations (and their antecedents in third world nations governments) and the new forms of relationship that evolved between people - and with the state - within the urban population especially of the middle and upper classes who acquired a social life with more room for individual interests. In an ideal civil society, people engage in horizontal networks to promote shared ideas and concern. They are expected to act freely, without constraints from the state or other individuals (whether family or religious leaders), and to form associations that bridge divisions based on gender, religion or ethnicity (Moksness, 2010).

While the plethora of accounts of power is complex, the complexity is one of requisite variety. What emerges is that power is not a single entity. It represents a cluster of concepts. Power as domination, which is linked to (the capacity for) violent agency, is the dominant perception of power in everyday speech and quite likely, would represent the majority of the combined 470 million Google hit for 'social' and political power, if we were to examine them. However, if we look to the academic social science literature, increasingly the conception of power as essentially grounded in coercion represents a minority view. One of the characteristics of the development of the literature over the last thirty years has been a move from this 'common sense' view to more systemic, less agent specific, perception of power that see it as more generally constitutive of reality. Such a move is coupled with a more inclusive perception of the concept; whereby the idea that there is a single thing-in-the-world corresponding to power, as some kind of essence, has fallen out of favour (Haugaard \& Clegg, 2008).

Power is the ability to influence the behaviour of people while authority is often used for power perceived as legitimate by the social structure of society or organisation. Power is the ability to influence others to believe, behave or to value those in power desire them to strengthen, validate or confirm present beliefs, behaviour, or values. Power is the social force that allows select persons to mobilize others; to organise others to act in concert, and to melt away resistance to leaders' authority (Petress, 1996). In social terms, power, almost by definition involves the rule by the few over the majority and the political process - structural and interpersonal whereby power is legitimated (the process whereby power ceased to be nakedly coercive and becomes power that is based upon authority. Giddens (2009), notes that power is the ability of individuals or groups to make their own concerns or interests count, even where others resist. Power sometimes involves the direct use of force but is almost always also accompanied by the development of ideas (ideology) which justify the actions of the powerful and those who wield power in the society. The nature of the ideology and its intent is another question and calls for critical examination. Power is the probability that one actor within a social relationship will be in a position to carry out his will despite resistance regardless of the basis on which this probability rests (www.sociology.org.un).

In social and political theory, power is often regarded as an essentially contested concept (Luke, 2005). One of such contrast and disagreement sets those who define power as getting someone else to do what you want them to do i.e. an exercise of power over, against those who define it as an ability or a capacity to act as the classical definitions by Weber depicts. Similarly, Foucault (1983) posited that if we speak of the structures or the mechanisms of power, it is only insofar as we supposed that some exercise power over others. Here power is depicted in terms of power over relations and is defined in terms of its actual exercise. Pitkins (1972:276) notes that power is related etymologically to suggest that power is a something-anything-which makes or renders somebody able to do, capable of doing something. Power is capacity, potential, ability or wherewithal to do something in power relations.

Power is a dispositional concept, meaning that power is a potentiality, not an actuality - indeed a potentiality that may never be actualized (Morriss, 2005:69). This definition amounts to a significant revision of Luke's earlier analysis of power, in which he argued against defining power as power - on the grounds that such definition observes 'the conflictual aspect of power - the fact that it is exercised over people' and thus fails to address what we care about most when we decide to study power. Arendt (1970) distinguishes power sharply from authority, strength, force and violence and offer a normative account in which power is understood as an end in itself and this has the effect of screening any and all strategic understanding of power (where power is understood in the Weberian sense earlier discussed as imposing one's will on another) out of the analysis. Allen (1999) defines power over others as a capacity namely; the capacity to impose ones will on others, on this view, power over is a derivation of power to. But Wartenberg (1990) however argued that power over and power to refer to fundamentally different meanings of the word 'power' and that it is a mistake to try to develop an account of power that integrates these two concepts.

Power can also be discussed in terms of the actions or the dispositional abilities of the particular actors - and broader systemic or constitutive conceptions of power i.e. those that view power as systematically structuring possibilities 
for action or more strongly, as constituting actors and the social world in which they act. The systemic conception thus highlights the ways in which given social system cover differentials of dispositional power on agents; thus structuring their possibilities for action (Haugaard, 2010:425). The systemic conception thus highlights the ways in which bread historical, political, economic, cultural and social forces enable some individuals to exercise power over others, or inculcate certain abilities and dispositions in some actors but not in others. Saar (2010) maintains that the systemic conception of power should be understood not as an alternative to the action theoretical conception of power, but rather as a more complex and sophisticated variant of that model.

The constitutive conception of power focuses on the fundamentally trans-individual and relational ways in which individual and the social worlds they inhabit are themselves constituted by power relations. The roots of this constitutive conception can be credited to Spinoza (2002), and also found in the work of Arendt and Foucault (earlier discussed). Arendt, for example, posited that if we speak of the structures or the mechanisms of power, it is only insofar as we suppose that certain persons exercise power over others. The constitutive conception of power was also evident in Foucault's (2000) definitions. According to him, power is the multiplicity of force relations immanent in the sphere in which they operate and which constitute their own organisations; as the processes which through ceaseless struggles and confrontations, transforms, strengthens, or reverses them... thus forming a chain or system.

What informed the highly contested nature of the concept of power is shaped by the political and theoretical interests that the scholar or analyst brings to the study of power (Said, 1986). The democratic theorists are interested in different things when they study power than are social movement theorists. Our interest in power in this paper is how it affects the social-political relationship between those that wield power (the elected and political office holders) and the Nigerians who supposedly give them the initial power through elections as their representatives. The question is where does the power reside in the Nigerian polity - in the people or the fragment inconsequential powers given to the people by the political class and power holders?

\section{Democratic Values and Civil Society}

Over the past decades, democratic values and responsive governance have been the top priorities of civil societies. Civil societies themselves have been considered increasingly important to socio-economic development and in political mobilisation especially in developing countries. This is partly an effect of neo-liberal reforms that have decreased state responsibilities in certain economics as well as political issues, instead increasing the role of not only private actors but also non-governmental organisations. Furthermore, the democracy reforms of the last decades and the heightened focus on human rights have strengthened the political agency of civil movements and organisations, which often have turned into driving critics of precisely the lack of democracy in governance (Melin and Moksnes, 2010).

The civil societies all over the world helps to promote democracy by manifesting civil engagement, having internally egalitarian and transparent structures, promotion of democratic ideals and by standing free from state influence are able to demand transparency and accountability of government and its officials, and in the process press for popular participation in political decision-making on different levels.

According to Tragardh (2010), the notion of civil society depicts a relation between state and people that is constituted in a specific way. First, it implies that people regard themselves as political subjects in relation to a state, and as autonomous individuals, carrying certain rights which they demand from the state and to some extent expect the state to give i.e they see or regard themselves as 'citizens'. Civil society then is constituted by such citizens, in the sphere between the individual and the state. In social theory, civil society is a space where state and society interact with one another and allow continuous two-way communication. The achievement of differentiation and plurality in modern social institutions is justifiably taken into account. Social utopias of de-differentiation can be avoided by a three-level theory of society, where civil society occupies the sphere between economy and the state. The degree of heterogeneity and plurality of a given society not only reflects the extent to which civil society experiences a transformation along modern lines, but also implicates the possibilities of civil society's ability to create and endure a coherent democratic polity (White, 1994:388).

In Nigeria, the civil societies have been a veritable tool for democratic transitions and transformations. Okello (2010) posited that civil society in Nigeria struggle for democratic transformation has, for most part wrapped itself up in the language of political and civil rights. The agitation has been moored rather strongly on the libertarian orthodoxy, which privileges freedom and competition, both seen as the necessary conditions or ingredients for a better democratic outcome". NADECO and other civil organizations like Democratic Alternative (DA) and others teamed up to give the military junta a good fight for the restoration of democratic governance in Nigeria. 
But does this means that civil societies in Nigeria are effective and sure vanguard of the general will? The answer is no. This is because their modus operandi, life style and association with the upper class reveal that the civil societies in Nigeria, especially the Non Governmental Organization (NGOs) are not really what they claim to be. Many of the leaders of the civil societies are stupendously rich, affluent and friends of the ruling class. Many of them were former government officials who lost out in power tussle or in election and quickly turn to the so-called masses to find solace and launch their 'war of frustration' on the government.

The gains of civil society in the circumstances of the politics of clienteles that prevails in Nigeria today are dented by their very associations and focus. The Nigerian ruling class does not fit readily into the social fabric of their segments of society and thus lack the legitimacy to hold on to power over their own people. To win the loyalty of the people, the politicians promised an increase in benefits and other incentives such as land, cash and patronage for loyalists (Ekeh, 1975 and Osaghae, 2006). The bifurcated public realm makes civil society an arena of vigorous contestation, far from the peaceful harmony of pluralistic governance processes. Civil society in its African status quo is seemingly not able to play a consistent and effective role in participatory governance processes or to contribute to pluralistic decision making process (Barber, 2004).

\section{Democracy The People and Loci of Power in Nigeria}

The larger objective of democracy is to enable citizens to participate in decisions that affect their collective and individual lives. In this context the civil societies and the people create the enabling environments for citizens to effectively take part in political and decision-making processes, in order that their collective interests and rights are translated into action, and government made to be more responsive, responsible and accountable to the peoples' will. (Espinoza, 2010). Bradham (1993) posited that democracy has three basic aspects or trait; basic minimum civil and political rights engaged by citizens; procedures of accountability in day to day administration under some over-arching constitutional rules of the game; and period exercises in electoral representativeness.

Democratic government was installed or sworn in 1999 after 16 years of military dictatorship. On the inauguration of the democratic civilian administration, Nigerians heaved a sigh of relief and were happy to see the exit of draconian, dictatorial, oppressive, insensitive, self serving retrogressive and destructive military administrations which brought more pain and trauma than gains to Nigerians. Nigerians thought the much awaited Eldorado has arrived. Rapid development and all-embracing growth were some of the expectations of Nigeria. But after 14 years of democratic governance, the growth and sustainable development of Nigeria seem to be a mirage. All over the World, there is usually a correlation between democracy and development (Przeworski \& Limongi, 1983; Duncan et al, 2009; Williams et al, 2009; RiveraBatiz, 2002).

Osaghae (1994) discusses democracy as a process paradigm and sees democracy as an on-going process influenced by past politico-institutional history of the democratizing society and whose survival depends on its consequence for the people, on how much it is able to better their material conditions in terms of literacy, security of life and property, better health, employment, food security, portable water and rural development as well as ensure political stability. Participatory democracy which Stigliz (2002) termed participation perspective is broader than the conventional democracy and includes the involvement of people not only in choosing political representatives but it being included and empowered in the process through which decisions are reached in the various layers of society. One of the veritable participation method is giving people a voice and influence to affect the critical decisions affecting their lives and the nation, but in Nigeria like other many third world countries the absence of voice of the people is the norm and lack of greater transparency and openness in socio-political and economic decisions which often result in gridlock and retrogression (Olorinmoye, 2010).

Since Nigeria's transition from military to civilian democratic rule in 1999 there are events and circumstances to conclude that power actually reside in the government officials and their cronies, agents, praise singers, sycophants and loyalists. Ochonu (2004) succinctly captures the Nigerian scenario when he writes that 'the way in which power is wielded and performed in the current political dispensation in Nigeria bears out and complicates Foucault's thesis of subtle and stealthy power at the same time; it is at once crudely physical and invincibly subtle. It is so brutally real that one can only speak of a power knowledge regime with some intellectual trepidation. At the same time, it takes such subtle and discursive forms that it makes contemporary Nigeria some kind of ethnographic present for Foucault's thesis. Nigeria's political leaders, especially state governors, have been employing the carrot and the stick in a strategic exercise of power.

The average Nigerian political office holders and power wielders are demi-gods and sort of 'Czars' with fiefdom. 
Their actions and dispositions seek to engender consent and popularity. Ochonu (2004) noted that "political office holders have been gently but steadily planting their persona and their image on the landscape by inscribing their names on any edifice with the remotest connection to their tenure and such an act is packed with power implication. These political office holders hire thugs and state security agents and intimidate opponents and dissenting members of the public." The theatrics of power unfolding in Nigeria mirrors a dangerous escalation of a familiar trend - an abuse of power that is so entrenched that it renders alternative forms aberrant. The exercises of power in Nigeria by political office holders include any method - direct or indirect, brutal and crude. The behaviours of these political office holders are more or less megalomaniac and narcissistic inclinations.

The political office holder manifest power and authority as if there is no tomorrow:

- They go in long convoy of hybrid, expensive and bullet proof SUV vehicles.

- They drive so recklessly on the roads as if there are no other road users, and this has caused series of accidents resulting in deaths of hundreds of Nigerians including the late Prof. Festus lyayi who was killed by the convoy of Kogi State Governor on the $5^{\text {th }}$ November, 2013 on their way to National Executive Council (NEC) meeting in Kano in the North Central geo political zone of Nigeria.

- Political office holders always move around with a retinue of fierce looking and heavily armed security personnel who brutalise anybody that fails to stay clear of their paths or opposes them.

- They treat common Nigerians as vassals and second class citizens with reckless abandon.

- The civil societies and opposition members and those who criticize them are labelled as disgruntled elements, subversive ingrates and enemies of the state.

- They personalize power, opulence and authority in their dispositions, mien and actions on issues concerning the state and the people.

- The lack of power of recall of ineffective political representatives in Nigeria sort of compounds the situation and strengthens the grip of power by political office holders. The power of recall only exist on paper and have never been invoked anywhere in Nigeria.

The political office holders recently innovated a slogan/term "the dividends of democracy" to describe ridiculous and scanty projects which they often name after themselves and personify the state as synonymous with their names and what they stand for. This slogan of "dividends of democracy" insults and denigrates the people - the electorates who actually voted them in. The above slogan portray the democratic governance as business enterprise or the like whereby shareholders are paid some dividends at the end of a period. This is an unfortunate trend. A senator gets the sum of N500,000,000 (Five Hundred Million Naira only) as constituency development fund, but sinks 10 pipe-borne water bores holes in some communities at an inflated rate and pocket the rest, and calls the bore holes projects 'dividends of democracy'. At the end of four years, a senator in Nigeria gets 2 Billion Naira as constituency fund with nothing to show for it. They move about in opulence, in flashy cars and criss-cross the world globe, trotting.

The people who are ideally supposed to wield political power are silenced in all ramifications. The people are forced to join in singing the slogans of the demi-gods politicians. Such slogans like the 'king maker', 'Mr. fix it', 'talknado', 'action governor', 'strong man of Ibadan politics', 'onwa - the moon', 'Baba', 'messiah' etc, are some accolades Nigerian political office holders are known, yet poverty, retrogression and comatose economy are the story of the Nigerian people. Power indeed belongs to the political office holders and not the people and this is an anathema to democratic values and good governance.

\section{Implication for Socio-economic and Policy Development in Nigeria}

The abuse of power and authority in Nigeria calls for a deep reflection by all stakeholders especially the academia. There is the need for a critical approach to advocacy and other social engagements in Nigeria by the social workers. There is also the need to politicise the oppressive forces in Nigeria and the dehumanization of Nigerians. Social workers should collaborate with other stakeholders like the civil societies and other NGOs on civic and political education and awareness and on how to reduce the powers of the so-called elected officials and state agents.

This scenario also has a serious policy implication for the socio-economic development of Nigeria. If the right policies and laws are put in place to limit the powers and excesses of the political office holders, this will go a long way in reforming the Nigerian society and the way political games are played. This will result in the evolution of democratic values systems that will turn the fortunes of Nigeria around for good and for the benefit of all Nigerians especially the masses. 


\section{Conclusion}

The democratic experience in Nigeria negates the principles of democratic values where power supposedly belonging to the people the electorates but is exercised by the political office holders. The exercise of power bewildering mix of blackmail, oppression, thuggery, opulence and affluence in midst of abject poverty and silenced masses are the best way to describe governance in Nigeria. The Nigerian political office holders have stripped Nigerians of their powers and privileges as evident in their mien, actions and activities and hence power resides and belongs to them, rather than the people. As Ochonu (2004) rightly posited, a democratic system that lays emphasis on image, acceptance and popularity leads elected officials to invent and reinvent ways of performing power that are a depressing throwback to military rule. This is against the grains of democratic governance and perhaps an invention to the world from Nigeria on how power is exercised.

\section{References}

Arendt, H. (1970). On Violence. New York, Harcourt Brace \& Co.

Berber, B. (2004). Strong Democracy: Participator Politics for a New Age. Berkeley. University of California Press.

Bradhan, P. (2001). The Structures of Intergovernmental Relations in Nigeria. International Social Science Journal 167: 121-127.

Ekeh, P. (1975). Colonialism and Two Publics in Africa: A Theoretical Statement. Comparative Studies Vol 20 No 2 pp 221-290.

Espinoza, V. (2010). How civil society participates in multilateral political process. A paper delivered at power to the people: Contested civil society in search of democracy conference of Upsala Centre of Sustainable Development March 23-24 2010. Upsala, Sweden.

Feminist perspectives on power. Available on www.feministonpowerstanfordencyclopaedia ofphilosophy.html. (Accessed on 18/11/2013)

Foucault, M. (2000). Power. New York, New Press.

Foucault, M. (2000). The subject and power in essential works of Foucault 1954-1984. (Vol 3) edited by J. Faubion, New York: The New Press.

Giddens, A. (2009). Sociology Cambridge: Polity.

Haugaard, M. (2010). Power: A family resemblance concept. European Journal of Cultural Studies Vol 13 No 4 419-438.

Luke, S. (2005). Power. A radical view. London, Macmillan.

Moksnes, H. (2010). Introduction to the conference proceedings: Power to the people? (con)tested civil society in search of democracy. Organized by Upsala Centre for Sustainable Development, March 23-24, 2010, Upsala, Sweden.

Moksnes, H. And Melin, M. (eds) (2010). Power to the people contested civil society in search of democracy Upsala Centre of Sustainable Development, March 23-24 2010 conference, Upsala, Sweden.

Morris, P. (2002). Power. A philosophical Analysis. $2^{\text {nd }}$ edition Manchester. Manchester University Press.

Musa, A.B. (2005). Effective opposition as an antidote against abuse of power by the executives in Nigeria. A paper delivered at the international conference on sustainable democracy in Nigeria: Challenges and prospects.

Ochonu, M. (2004). Democracy and the performance of power: Observations from Nigeria. M.I. Publishing, University of Michigan Library.

Okello, D. (2010). Tensions in civil society participation in governance and politics in Africa. A paper delivered at power to the people: Contested civil society in search of democracy conference of Upsala Centre of Sustainable Development March 23-24 2010. Upsala, Sweden.

Olarinmoye, O. (2010). Democracy, participation and development in Nigeria's Fourth Republic 1999-2003. Turkish Journal of Politics Vol 1 No 2 63-77.

Osaghae, E. (2006). Colonialism and civil society in Africa: The perspective of Elaeh's two publics volunteers. International Journal of Voluntary and Non Profit Organizations 3(4) 132-145

Osaghae, E.E. (1994). The study of political transitions in Africa ROAPE, No. 64 Vol 22, 183-197.

Petress, K. (1996). Power" Definition, typology and description available on-line at www.uthsca.eduldocuments Ipowerdefinitions/typologyexamples (Accessed on the 21/11/2013)

Pitkin, H.F. (1972). Wittgenstein and justice: On the significance of Ludwig Wittgenstein for social and political thought: Berkeley, C.A. University of California Press.

Przeworski, A. and Limongi, F. (1997). Political regimes and economic growth: Journal of Economic Perspectives Vol 7, No 3 pg 51-69.

Rivera-Batiz, F.L. and Rivera-Batiz L.A. (2002). Democracy, participation and economic development: An introduction. Review of Development Economics Vol 6 No 2. 135-150.

Saar, Martin (2010). "Power and Critique". Journal of Power 3(1) 197-212.

Said, E. (1986). Foucault and the imagination of power in Foucault: A critical reader, David Couzens Hoy (ed) Oxford Blackwell.

Saugaard, M. and Clegg, S.R. (2008). Introduction: Why power is the central concept of the social sciences. New York. The Sage Handbook of Power.

Sharp, G. (2010). From dictatorship to democracy. A conceptual framework for liberation (4th $\mathrm{ed})$. Boston. Albert Einstein Institution.

Spinoza, B. (2002). Theological-political treatise in M.L. Morgan (ed) Complete works, Indianapolis: Hackett, pp 383-583.

Stigliz, J.E. (2002). Participation and development: Perspectives from the comprehensive development paradigm. Review of Development Economics Vol 6 No 2 163-182.

Tragardh, L. (2010). Contested Notions of Civil Society. A paper delivered at Power to the people: Contested civil society in search of democracy conference of Upsala Centre of Sustainable Development March 23-24 2010. Upsala, Sweden.

Wartenberg, T. (1990). The forms of power. From Domination to Transformation. Philadelphia: Temple University Press.

Weber, M. (1975). Economy and society: An outline of interpretive sociology: 2 Vol. Berkeley, C.A. University of California Press.

Weber, M. (1988; (First publish 1926). Max Weber, Biography: New Brunswick Transaction Books.

White, G. (1994). Civil Society, Democratization and Development Clearing the Analytical Ground in Democratisation Vol 1 No 3 autum.

Williams, G.; Ducan, A.; Landell-Mills, P. and Unsworth, S. (2009). 'Politics and Growth'. Development Policy Review Vol. 27 No. 1 5-31. 